port, is radio irreplaceable by other forms of communication. A general survey of the present state of the art of marine radio communication was given at a meeting of the Wireless Section of the Institution of Electrical Engineers on March 3, when Commander F. G. Loring and Messrs. W. L. McPherson and W. H. McAllister presented a paper entitled "A Survey of Marine Radio Progress, with Special Reference to R.M.S. Queen Mary". The first section of the paper comprised a short summary of progress during the last five years, with particular reference to the nature and volume of traffic, the types of communication involved, and the increasing use of direction-finding equipment by navigators. Next the types of equipment fitted in cargo vessels and the smaller class of passenger vessels were described. An account was then given of the radio problems encountered in the 'express steamer' class of vessel, and the paper concluded with a detailed description of the radio station of R.M.S. Queen Mary, the latest representative of its class. This installation comprises four transmitters and nine or ten receivers; the control room can handle four independent duplex circuits, and provision is made for high-speed transmission and reception, and simultaneous communication on both telegraphy and telephony with both sides of the Atlantic. The results of the experience obtained with this equipment have shown that in spite of the difficulties peculiar to ship installations of this character, by careful engineering, a good approach can be made to the operating efficiency of a large land station.

\section{Use of Diesel Locomotives in Mines.}

IN coal and metalliferous mines, as the working faces advance from the shafts, there is a desire to transport workmen to within easy reach of their working places and there is a large field of usefulness open to safe and convenient locomotives suitable for this purpose. Electric trolley, compressed air, storage battery, benzol and Diesel locomotives have been used, and it is interesting to note that tests have been carried out by the Ruhr Testing Station officials which show that Diesel locomotives are safe for use in mines. An investigation has been carried out by Messrs. George S. Rice and F. E. Harris of the United States Bureau of Mines, and a report has been published under the title of "Diesel Mine Locomotives -Development and Use in European Coal Mines" (a Publication of the Department of the Interior, United States Bureau of Mines, November, 1936). It is stated in this report that provided a reasonable amount of air is circulated along the roadways where these Diesel locomotives are in use, dangerous percentages of carbon monoxide do not occur if the machines are maintained in a good working order. These locomotives are being used in American mines, and they are being substituted for benzol locomotives in mines in Germany, Belgium and France. At a colliery in Scotland, a Diesel locomotive has been on trial since 1935. Another large colliery company in Yorkshire is contemplating using Diesel locomotives for carrying men from the pit bottom to points near the face, and the necessary investigations are at present being made. In Great Britain special permission is required to introduce internal combustion engines into mines by Section 58 of the Coal Mines Act, 1911, which prohibits the use of these engines in underground workings without permission.

\section{Air Survey}

ThE Air Survey Committee grew from a suggestion of the Army Council in 1919, and now includes representatives of the War Office, Air Ministry, Admiralty, Ordnance Survey and Department of Scientific and Industrial Research. The Committee's second report (Report of the Air Survey Committee No. 2. H.M. Stationery Office. 4s, net) reviews at length the methods of air survey and the apparatus at present available. A useful appendix analyses the cost of air survey. Conditions, of course, vary, and the estimate is based on the existence of an air survey organization on a permanent basis undertaking operations on a large scale. It is assumed that the area is undeveloped and consequently difficult for land transport. Under these conditions the cost of the survey is estimated for an area of one million square miles which would entail six years work for completion of the air photography. For this, five aircraft in action and one in reserve would be rerequired. This fleet could do 2,000 hours of photographic flying each year. The total cost, which of course includes the cost of photographic material, works out at twenty-three shillings per square mile, but considerably more if a smaller area is surveyed, rising to 180 shillings per square mile for an area of 500 square miles. These must be taken as average figures, and the cost would be much higher in urbanized areas. The production of the maps is additional to these costs.

\section{Works of Charles Darwin in Russian}

THE fiftieth anniversary in 1932 of Charles Darwin's death was marked with perhaps greater solemnity in the U.S.S.R. than elsewhere, since both Engels and Lenin adopted and popularized Darwin's evolutionary idea. Until that time, only more or less abbreviated translations of Darwin's works had been available to Russian readers, and most of them were out of print. It was therefore decided that a new translation should be published, which had to be the most complete of all editions of Darwin's works existing in any language. The preface to the first volume, published in 1935 by the State Publishing House for Biological and Medical Literature, Moscow and Leningrad, points out the necessity for such an edition, particularly at the present time when "the economic crisis and the political and spiritual reactions caused by it, not only call for a complete oblivion of Darwin, but when the bourgeoisie, in its futile struggle against darwinism, more and more often invokes the darwinism's decrepit antithesisreligious teachings on the creation of the world".

According to the plan, the edition will comprise twelve volumes, and will include the translations of all books, and all papers by Darwin, except some 